
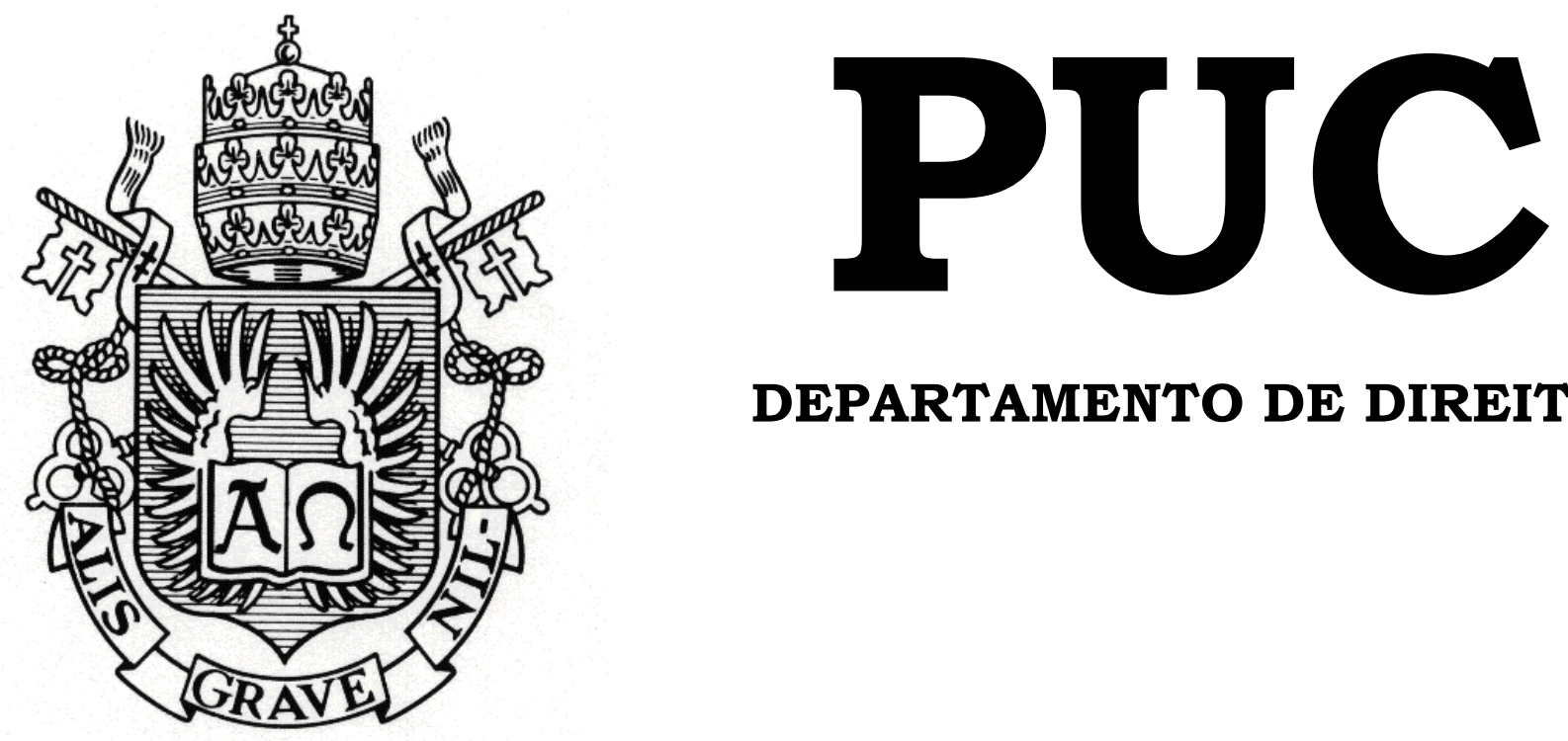

DEPARTAMENTO DE DIREITO

\title{
MATERNIDADE POR SUBSTITUIÇÃO NOS ESTADOS UNIDOS: ANÁLISE DE DOIS CASOS PARADIGMÁTICOS
}

\author{
por \\ MARINA PEPE RIBEIRO BARBOSA \\ ORIENTADORA: NÁDIA DE ARAÚJO \\ 2012.1
}

PONTIFÍCIA UNIVERSIDADE CATÓLICA DO RIO DE JANEIRO

RUA MARQUÊS DE SÃO VICENTE, 225 - CEP 22453-900 RIO DE JANEIRO - BRASIL 
MATERNIDADE POR SUBSTITUIÇÃO NOS ESTADOS UNIDOS: ANÁLISE DE DOIS CASOS PARADIGMÁTICOS

por

MARINA PEPE RIBEIRO BARBOSA

Monografia apresentada ao Departamento de Direito da Pontificia Universidade Católica do Rio de Janeiro (PUC-Rio) para a obtenção do Título de Bacharel em Direito.

Orientadora: Nádia de Araújo 


\section{Agradecimentos}

Aos meus pais, pelo apoio, esforço e confiança depositados em mim durante todos esses anos. Essa conquista, sem dúvida nenhuma, é mais do que minha, é de vocês.

Aos amigos, conquistados ao longo dessa jornada, pelo companheirismo e carinho, tantos nos bons quanto nos maus momentos. Vocês tornaram essa fase mais fácil e agradável.

À PUC e seu corpo docente, pelo brilhante trabalho realizado com seus alunos, transformando-nos em profissionais capazes e preparados para seguirmos os caminhos que escolhermos. 


\section{Resumo}

A presente monografia pretende abordar as peculiaridades e questões provenientes da utilização da maternidade por substituição como forma de reprodução humana assistida provando que o direito precisa caminhar em busca de uma legislação específica sobre a matéria para salvaguardar as partes envolvidas e trazer previsibilidade aqueles que pretendem recorrer a está pratica.

\section{Palavras - chave}

Reprodução humana assistida - Filiação - Maternidade por substituição Mãe gestacional - Mãe genética - Pretensos pais - Doador de material genético 


\section{Sumário}

Introdução

Capítulo I - A maternidade por substituição nos Estados Unidos

Aspectos gerais

Maternidade por substituição tradicional x maternidade por substituição gestacional 16

Maternidade por substituição altruística x Maternidade por substituição comercial_19

Maternidade por substituição comercial como fator de objetificação das partes

envolvidas 21

0 uso dos "Prebirth parentage orders" nos contratos de maternidade por substituição

Capítulo II - Estudo de casos___ 28

$1^{\circ}$ caso: Baby M - Supreme Court of New Jersey, 1988___ 28

Aspectos gerais _ 28

Da invalidade do contrato de maternidade por substituição firmado entre as partes _ 31

Da cessação do poder parental de Mary Beth Whitehead ___ 32

Dos direitos constitucionais e fundamentais em questão __ 34

Da custódia da criança _ 36

Da visitação da mãe substituta __ 37

$2^{\circ}$ caso: Calvert v. Johnson - Supreme Court of California, 1993

Aspectos gerais 39

Da intenção como principal fator para se definir a questão da maternidade __ 40

Do voto vencido - o melhor interesse da criança como fator determinante para se

definir a questão da maternidade __ 42

Maternidade por substituição tradicional x Maternidade por substituição gestacional 44 


\section{Introdução}

A infertilidade é um problema que vem afetando cada vez mais o mundo moderno. Isso se explica por razões sociais e ambientais, como o fato das mulheres estarem retardando sua vontade de ter filhos em nome de do trabalho ou de questões financeiras e a poluição cada vez maior.

Nesse contexto o uso das técnicas de reprodução humana assistida vem crescendo e desafiando o direito na medida em que estabelece novas formas de se conceber filhos e por consequência de se formar uma família. Tais técnicas muitas vezes criam situações que desconstroem o "natural", trazendo um impacto muito grande para a sociedade e mais especificamente para o mundo jurídico.

Já temos enraizado o entendimento de que as relações de filiação não necessariamente precisam contar com o elemento genético, "natural", para serem reconhecidas como tal. Um exemplo claro disso é o instituto da adoção no qual a relação da criança com os pais genéticos é rompida sendo posteriormente substituída pela relação com os pais adotivos ${ }^{1}$.

Outros institutos legais também nos confrontam com a ideia da não necessidade de conexão genética entre pais e filhos, como a presunção de que o marido da mãe é o pai do filho nascido na constância do casamento. As relações de filiação podem ser então estabelecidas de diversas formas, varias das quais não necessitam de exame de compatibilidade genética (DNA) para provar a conexão entre pais e filhos.

Além disso, a família tradicional composta por homem e mulher trazendo em si a ideia de filiação biológica não é mais a regra. A realidade social moderna nos coloca de frente com diversas outras formas de família, como as compostas por casais do mesmo sexo, o que ajuda a minimizar a importância da genética na hora de se estabelecer a filiação.

\footnotetext{
${ }^{1}$ Campbell, Angela, "Conceiving parents through law" (2007), International Journal of law, policy and the family. Pag. 245.
} 
A partir daí se defende que as relações de filiação na verdade se apoiam muito mais nas questões sociais e culturais do que nas questões genéticas.

Por outro lado, seria um erro negar o importante papel da genética nas relações de filiação. As leis modernas utilizam o exame de DNA para estabelecer a filiação quando esta é motivo de controvérsia. A genética se mostra então, ainda, uma maneira útil e de alguma forma precisa de se estabelecer a filiação e, por consequência, as responsabilidades perante a criança.

$\mathrm{Na}$ reprodução humana assistida a discussão sobre o papel da genética nas relações de filiação fica ainda mais latente. Os avanços nessa área possibilitaram a concepção de crianças através da utilização de óvulos, espermatozoides ou embriões de doadores, conhecidos ou anônimos, que normalmente não tem a intenção de se tornarem pais.

A ciência trouxe maneiras de famílias não tradicionais terem filhos, casais do mesmo sexo, pessoas solteiras e casais inférteis podem através das novas técnicas aumentarem suas famílias. Com isso, novas categorias legais tem que ser criadas para se definir as relações de filiação diante desta nova realidade.

O conceito tradicional de pai e mãe não pode mais ser universalizado, hoje o direito tem que considerar figuras como pais genéticos, mãe de substituição, pretensos pais, doador de gametas entre outros $^{2}$.

O pouco desenvolvimento do direito em face aos avanços científicos na área da reprodução humana assistida revela que estamos em uma esfera de incertezas, tanto por parte dos legisladores, quanto por parte dos juízes, principalmente quando os mesmos são instados a resolver questões de filiação de determinada criança nascida através dessas novas técnicas. Embora a reprodução humana assistida já exista e seja utilizada há mais de

\footnotetext{
2 Kingregan, Charles P., "Collaborative Reproduction and Rethinking Parentage" (2008), Journal of the American Academy of Matrimonial Lawyers. Pag. 3.
} 
25 anos os avanços legais tem sido lentos e não suficientes para responder as demandas advindas nesse campo.

O que temos visto ocorrer nas discussões do tema mundo afora é a ponderação de dois grandes fatores, identidade genética e projeto parental, procurando assim definir a quem e como estabelecer o poder parental.

Diante dessa realidade, o presente trabalho pretende fazer uma análise da maternidade por substituição como forma de reprodução humana assistida, discutindo suas peculiaridades dentro do contexto dos Estados Unidos.

Os Estados Unidos foi escolhido por se tratar de um país onde a discussão sobre o assunto está mais evoluída podendo assim servir de parâmetro para as outras nações já que o tema é relativamente recente e encontrasse em construção em todo o mundo.

Os contratos de maternidade por substituição são totalmente proibidos, por exemplo, na Áustria, Egito, França, Alemanha, Itália, Japão, Holanda, Espanha e Suíça. Por outro lado, países como Ucrânia e Índia, além de permitirem esse tipo de contrato, ainda criam situações favoráveis para que estrangeiros possam realizar lá o que é proibido em seus países de origem.

No Brasil, a matéria é de competência da União porém, não existe lei federal regulando a matéria. O que existe é uma resolução do Conselho Federal de Medicina (Resolução No 1.975/2010/CFM), autarquia federal, órgão de classe da profissão médica.

Tal resolução, determina que a gestante substituta tenha parentesco de até segundo grau com a doadora genética, salvo autorização do conselho para outros casos. A doadora genética por sua vez, deve apresentar problema medico que impeça ou torne perigosa a gestação.

Além disso, o único modelo autorizado pela resolução do CFM é o modelo altruístico, tanto em relação a possíveis doadores quanto a gestante substituta. 
A proibição ou restrição legal da maioria dos países a esse tipo de contrato combinada com a liberação em poucos países faz com que muitos pretensos pais acabem por buscar o serviço das mães substitutas no exterior. Tal pratica foi facilitada pelo advento da internet e de outras modernas formas de comunicação, além é claro da facilidade de se fazer viagens internacionais nos dias de hoje $\mathrm{e}^{3}$.

A maternidade por substituição já é com certeza um fenómeno global. Dados recentes mostram que os pretensos pais podem vir das mais variadas regiões, como Europa, América do Norte, Austrália e Asia. Temos visto inclusive que em uma mesma maternidade por substituição podem estar presentes representantes de mais de dois Estados ${ }^{4}$.

Os principais problemas decorrentes da maternidade por substituição realizada internacionalmente são a incerteza sobre a filiação (problema existente também na maternidade por substituição nacional quando não há legislação sobre o tema no país) e a nacionalidade da criança nascida através desta pratica.

Tais problemas chegam normalmente ao conhecimento das autoridades do país de origem dos pretensos pais de duas maneiras: através do consulado do país de origem no país onde foi realizada a maternidade por substituição com os pretensos pais requerendo o passaporte ou documentos válidos para que possam levar a criança para casa, ou quando os pretensos pais já estão de volta com a criança no seu país de origem e procuram as autoridades para regularizar a sua situação ${ }^{5}$.

As autoridades então ficam frente a frente com as questões da filiação e da nacionalidade, tendo que decidir quem são os pais legais de acordo com suas leis e se aquela criança pode ou não adquirir a

\footnotetext{
3 Permanent Bureau, "Preliminary report on the issues arising from international surrogacy arrangements" (2012), Prel. Doc. No 10, Hague conference on private international law. Pag. 6. ${ }^{4}$ Permanent Bureau, "Preliminary report on the issues arising from international surrogacy arrangements" (2012), Prel. Doc. No 10, Hague conference on private international law. Pag. 7.

5 Permanent Bureau, "Preliminary report on the issues arising from international surrogacy arrangements" (2012), Prel. Doc. No 10, Hague conference on private international law. Pag. 17.
} 
nacionalidade daquele país. A resposta para a segunda pergunta na maioria das vezes depende da resposta da primeira.

Tais variáveis podem gerar graves problemas para os envolvidos. As crianças podem acabar por ficar presas no país onde nasceram sem conseguir ir para casa já que segundo as leis do país de origem dos pretensos pais eles não seriam os verdadeiros pais e por isso, elas não seriam nacionais do país.

Ou mesmo se os pretensos pais tiverem conseguido mecanismos de levar seus filhos pra o país de origem as crianças podem acabar por ficar desprotegidas, já que muitas vezes não conseguirão ser registradas.

A vulnerabilidade dos participantes da maternidade por substituição também tem recebido atenção internacional. A preocupação maior é no sentido de se evitar a exploração, incluindo aqui o tráfico de crianças e mulheres, que pode surgir principalmente quando essas negociações contam com o auxilio de intermediários ${ }^{6}$.

Os Estados que proíbem a maternidade por substituição normalmente se baseiam na ideia de que tal pratica viola a dignidade tanto das mulheres como das crianças envolvidas, reduzindo-as a meros objetos de um contrato. Em muitos desses países entrar em um contrato de maternidade por substituição pode levar até a sanções criminais.

Nesses locais serão aplicadas as regras gerais de filiação do país, ou seja, normalmente a mãe substituta será declarada a mãe legal e seu marido, se ela tiver um, o pai. Os pretensos pais poderão em alguns locais adotar a criança e com isso passar a ter poderes parentais sobre a ela. Porém, isso não será sempre possível já que muitos países proíbem a participação dos pretensos pais anteriormente ao nascimento nos casos de adoção.

Já nos países onde a maternidade por substituição é permitida vemos dois tipos de legislação. Em alguns casos os contratos devem ser pré aprovados, verificando-se se a legislação existente sobre o assunto está

${ }^{6}$ Permanent Bureau, "Preliminary report on the issues arising from international surrogacy arrangements" (2012), Prel. Doc. No 10, Hague conference on private international law. Pag. 4 e 5. 
mesmo sendo cumprida. Em outros casos o foco é na transferência do poder parental após o nascimento da criança, e só aqui será verificado se a legislação existente foi cumprida, possibilitando então a transferência do poder parental da mãe substituta para os pretensos pais.

Existem ainda países onde a situação ainda não está regulamentada. Nesses países normalmente não há proibição expressa a maternidade por substituição, mas existe orientação no sentido de que tais contratos devem ser evitados.

Aqui, como nos países onde a maternidade por substituição é proibida, serão aplicados as regras gerais que dizem respeito a filiação, ou seja, na maioria dos casos a mãe substituta será considerada a mãe legal e seu marido, se houver, o pai. 


\section{Capítulo I - A maternidade por substituição nos Estados Unidos}

\section{Aspectos gerais}

É de conhecimento geral que os avanços científicos que possibilitaram a reprodução humana assistida trouxeram muitos desafios para o mundo jurídico e os Estados Unidos, assim como a maior parte da sociedade, parecem seguir a regra de primeiro desenvolver e aperfeiçoar novas técnicas médicas e científicas e apenas depois consultar o direito para saber se realmente poderiam fazer o que na verdade já estão fazendo ${ }^{7}$. Mas quem poderia prever que um conceito tão básico como maternidade poderia ser abalado por essas novas técnicas.

A definição da palavra mãe parecia trazer em si um conceito inabalável, mãe era aquela que dava a luz ao bebê ("mater est quan gestatio"). Seus deveres e responsabilidades poderiam até ser motivo de discussão, mas nunca sua identidade ${ }^{8}$.

Com o advento da reprodução humana assistida, mais especificamente da maternidade por substituição, a gestação, passou a não mais configurar como um fator essencial para a definição da maternidade ${ }^{9}$.

Maternidade por substituição é o nome dado ao negócio jurídico no qual uma mulher fica intencionalmente grávida de um bebê que ela não pretende criar. $\mathrm{Na}$ maioria dos casos ela o faz, altruística ou comercialmente, para uma pessoa ou casal que não poderia ter filhos de maneira natural, e que pretende ficar com os direitos e deveres parentais sobre a criança após o nascimento.

Assim como na maternidade por substituição internacional, a maternidade por substituição nos EUA é controvertida, enquanto alguns

\footnotetext{
7 Ingram, John Dwight, "Surrogate gestator: a new and honorable profession" (1993), Marquette law review, volume 76. Pag. 675.

${ }^{8}$ Kingregan, Charles P., "Collaborative Reproduction and Rethinking Parentage" (2008), Journal of the American Academy of Matrimonial Lawyers. Pag. 1.

${ }^{9}$ Walker, Veneta Cormier, "Surrogate motherhood in California: Will the real (legal) mother please stand” (2000), San Francisco Law Review, Volume 9. Pag. 33.
} 
estados como a Califórnia tem uma visão permissiva desse tipo de contrato, outros, como Michigan, o proíbem e aplicam sanções penais aos seus participantes.

É importante lembrar que a infertilidade como problema de saúde, não é o único motivo para a que muitas pessoas não consigam ou não optem por ter filhos naturalmente. Muitas delas são férteis e capazes de produzir embriões saudáveis, porém a gravidez pode ser perigosa para as mulheres com problemas de saúde, como diabetes ou pressão alta.

A nova realidade social em que vivemos traz também barreiras em relação a reprodução humana dita natural. Hoje temos um número grande de casais homoafetivos e pessoas sozinhas que buscam as técnicas de reprodução humana assistida e a maternidade por substituição como uma maneira de driblar as dificuldades em reproduzir-se.

Além disso, algumas mulheres escolhem a maternidade por substituição simplesmente por conveniência já que uma gravidez poderia impactar em suas carreiras ou estilo de vida.

Por outro lado, a maioria das mulheres que servem como mães substitutas nos EUA não entram nesse tipo de contrato apenas pelo dinheiro que pode estar envolvido. Normalmente elas sentem que estão realizando um importante papel e um serviço único e valioso para a sociedade ${ }^{10}$.

Muitas não calculam entretanto, os riscos e perigos envolvidos em uma gravidez, como pressão alta e diabetes gestacionais, além de depressão pós parto e o perigo de gravidez múltipla muito elevado em procedimentos de fertilização.

As crianças por sua vez também são muito impactados pela maternidade por substituição, tanto as que nascem através dessa técnica, como as que estão esperando para serem adotadas ${ }^{11}$.

A situação das crianças nascidas através da maternidade por substituição é preocupante porque não temos como prever como elas irão

\footnotetext{
10 Surrogacy in the united states (2011). Pag. 3.

11 Ryznar, Margaret, "International commercial surrogacy and its parties" (2010), The John Marshall Law Review. Pag. 1031 e 1032.
} 
reagir no futuro ao saberem que são fruto de tal pratica, muitas vezes feita de maneira comercial.

Muitas apresentam problemas psicológicos em decorrência da confusão causada pela dificuldade em assimilar as circunstâncias do seu nascimento. Problemas na formação da identidade e desejo de se reconectar com suas origens podem ser comuns.

Além disso, a falta de legislação específica em muitos estados deixa a situação dessas crianças em aberto nos casos de disputas judiciais entre a pretensa mãe e a mãe substituta e também em casos de separação dos pretensos pais. O destino dessas crianças é na maioria dos casos decidido com base no melhor interesse das mesmas.

Porém, tanto a genética, como a gestação e a intenção vem sendo levantados como fatores para se definir a maternidade em situações de disputa na maternidade por substituição.

Aqueles que defendem a gestação como fator primordial para definição da maternidade entendem que a gestante tem uma contribuição essencial não só para o desenvolvimento físico mas também, emocional e psicológico da criança. Segundo esta corrente existem evidências de que o ambiente intra uterino seria determinante para a formação da personalidade da criança ${ }^{12}$.

Esta corrente também defende que os laços desenvolvidos entre a criança e a gestante durante os nove meses de gestação devem pesar em favor da gestante na definição da maternidade, já que até aqui ela é a única que tem realmente algum laço com a criança.

O fato da intenção de ser mãe da gestante por substituição só ter aparecido durante a gravidez ou até mesmo após o nascimento da criança não a torna menos importante que a intenção da mãe que buscou o

\footnotetext{
12 Rae, Scott B., "Whose child is this? Defining the mother in surrogate motherhood arrangements" (1994), Journal of women's health, Volume 3, Number 1. Pag. 52 e 53.
} 
nascimento da criança através das técnicas de reprodução humana assistida $^{13}$.

Já aqueles que defendem a genética como fator determinante na definição da maternidade entendem que diferentemente da influência da gestação que não é certa, a influência da genética na formação de um ser humano é inequívoca.

Segundo esta corrente é a combinação de genes que dá a cada ser humano suas características únicas, e essas características são uma parte substancial da identidade de cada pessoa.

Para ilustrar esse ponto de vista a corrente em favor da genética como fator de definição da maternidade alega que se o embrião implantado na mãe substituta fosse implantado em qualquer outra mulher a criança seria a mesma. Não importa quem é a gestante, a criança sempre será a mesma formada em razão do material genético utilizado ${ }^{14}$.

A última corrente por sua vez defende a intenção de ser mãe e criar a criança como fator determinante na definição da maternidade nos casos de reprodução humana assistida.

Essa corrente entende que a maternidade nos casos de reprodução humana assistida deve ser definida analisando o processo como um todo e não apenas o nascimento ${ }^{15}$.

Para eles a intenção de ter a criança, o aspecto mental da concepção é o mais importante e por isso a mãe que inicia o processo de reprodução humana assistida deve ser considerada a mãe legal.

$\mathrm{Na}$ maioria das vezes, verificamos que as disputas são fruto do interesse de mais de uma pessoa na mesma criança nascida através da maternidade por substituição, mas o inverso também pode ser observado e

\footnotetext{
13 Rae, Scott B., "Whose child is this? Defining the mother in surrogate motherhood arrangements" (1994), Journal of women's health, Volume 3, Number 1. Pag. 61.

14 Rae, Scott B., "Whose child is this? Defining the mother in surrogate motherhood arrangements" (1994), Journal of women's health, Volume 3, Number 1. Pag. 56 e 57.

15 Rae, Scott B., "Whose child is this? Defining the mother in surrogate motherhood arrangements" (1994), Journal of women's health, Volume 3, Number 1. Pag. 59.
} 
pode muitas vezes ser até mais complicado e traumático para a criança envolvida.

Existem situações em que o interesse dos pretensos pais pela criança acaba, tal desinteresse pode ser motivado pela separação dos pretensos pais ou até por problemas de saúde descobertos na criança.

Já as crianças esperando por adoção também são impactadas pela maternidade por substituição na medida em que tanto a adoção, como a maternidade por substituição, são meios das pessoas aumentarem suas famílias.

Como, os procedimentos para se adotar uma criança tanto nos EUA, como internacionalmente, são demorados e burocráticos muitas pessoas acabam optando primeiramente por tentar a maternidade por substituição.

Além disso, a maternidade por substituição se mostra uma opção mais tentadora que a adoção quando analisamos a importância que a sociedade dá a perpetuação da família e do nome através dos laços de sangue. Através da maternidade por substituição um casal consegue ter um filho que poderá ser ligado geneticamente aos dois ou a pelo menos um deles.

\section{Maternidade por substituição tradicional $x$ maternidade por substituição gestacional}

A maternidade por substituição é normalmente dividida em dois tipos, a maternidade por substituição tradicional e a maternidade por substituição gestacional.

No contrato de maternidade por substituição tradicional, a gestante por substituição concorda em engravidar, normalmente através de inseminação artificial, utilizando seu próprio óvulo. O bebê então é geneticamente relacionado a ela. O espermatozoide pode ser do pretenso pai ou de um doador.

Por usar seu próprio óvulo e por isso a criança ser geneticamente relacionada a ela a gestante por substituição que engravida através da 
técnica tradicional é considerada a mãe biológica, genética e gestacional da criança fruto deste contrato ${ }^{16}$. Ficando apenas a maternidade como projeto parental com a pretensa mãe.

Já na maternidade por substituição gestacional, a gestante por substituição concorda em ser implantada por um embrião, gerado através da fertilização in vitro, que não tem nenhuma relação genética com ela. Tal embrião pode ser produzido utilizando-se os gametas de ambos os pretensos pais, de um deles e de um doador ou exclusivamente de doadores.

A distinção entre os dois tipos de maternidade por substituição é importante porque segundo as leis existentes nos EUA uma criança não pode ser dada em adoção antes de nascer. Isso porque a mãe não teria meios de dar um consentimento válido e informado para a entrega do bebê antes do nascimento e de todo o processo de gravidez e parto. Por isso, muitos estados proíbem a maternidade por substituição tradicional.

Porém, quando a criança não é geneticamente relacionada a mãe substituta, e sim aos pretensos pais ou a doadores, a lei e os argumentos mudam e passam a estar em favor dos pretensos pais, dando maior valor ao projeto parental.

A maternidade por substituição gestacional mudou a maneira das pessoas verem os contratos de maternidade por substituição, diminuiu o papel da gestante de substituição e aumentou a importância dos pretensos pais. As evidências provam que as próprias gestantes veem a situação de maneira diferente quando não estão geneticamente ligadas as criança.

A gestante substituta cria uma concepção nesses casos de que o bebê não é dela e sim dos pretensos pais e com isso fica mais fácil entrega-lo após o nascimento.

Vale dizer que o processo de inseminação artificial utilizado na maioria dos casos de maternidade por substituição tradicional é menos custoso que o de fertilização in vitro necessariamente utilizado na

\footnotetext{
${ }^{16}$ Gugucheva, Magdalina, "Surrogacy in America" (2010). Council for Responsible Genetics. Pag. 6.
} 
maternidade por substituição gestacional, o que poderia contribuir para explicar a escolha de algumas pessoas por essa primeira pratica, apesar da menor aceitação das leis e da jurisprudência a ela ${ }^{17}$.

A maternidade por substituição dentro do contexto da divisão entre maternidade por substituição tradicional ou gestacional pode se dar então de diversas maneiras:

Tipo 1. Ambos os pretensos pais contribuem com o material genético para a formação do embrião que será implantado na gestante substituta. O embrião será formado através da fertilização in vitro. Os pretensos pais aqui precisam ser necessariamente um casal heterossexual. Eles terão a seu favor a filiação genética. É espécie de maternidade por substituição gestacional.

Tipo 2. Apenas um dos pretensos pais contribui com o material genético. O embrião será formado então com a ajuda do material genético de um doador, que na maioria dos casos é anónimo. A criança terá ligação genética apenas com um dos pretensos pais. O leque de possibilidades de pretensos pais aqui é mais abrangente, podendo ser um casal hetero ou homossexual ou até mesmo pessoas solteiras. É também espécie de maternidade por substituição gestacional.

Tipo 3. O material genético utilizado para a formação do embrião é exclusivamente de doadores. Nem os pretensos pais, nem a gestante por substituição tem ligação genética com a criança. Aqui os pretensos pais poderão ser também casais hetero ou homossexuais ou pessoas solteiras. É mais uma espécie de maternidade por substituição gestacional.

Tipo 4. É utilizado o material genético da gestante substituta e do pretenso pai, na maioria das vezes o procedimento utilizado será a inseminação artificial. A filiação genética estará ligada ao pretenso pai e a gestante por substituição e por isso pode ser realizada por casais

\footnotetext{
17 Gugucheva, Magdalina, "Surrogacy in America" (2010). Council for Responsible Genetics.
} Pag. 6. 
heterossexuais, homossexuais masculinos ou homens sozinhos. É espécie de maternidade por substituição tradicional.

Tipo 5. Também espécie de maternidade por substituição tradicional. É utilizado o material genético da gestante substituta e de um doador, na maioria dos casos anónimo. A filiação genética está ligada a mãe substituta e ao doador. Pode ser usada por casais hetero ou homossexuais ou por pessoas sozinhas de qualquer sexo.

\section{Maternidade por substituição altruística $x$ Maternidade por substituição comercial}

A maternidade por substituição pode sofrer ainda mais uma divisão, sendo chamada altruística, quando nenhuma remuneração é paga pelos serviços da mãe substituta, ou comercial, quando uma remuneração é paga pelos serviços da mãe substituta.

Quando se fala em remuneração quer- se dizer um excedente ao pago em razão das despesas medicas da mãe substituta, já que tanto na maternidade por substituição altruística, como na comercial as despesas médicas ficam normalmente por conta dos pretensos pais.

A principal crítica que se faz a maternidade por substituição comercial diz respeito a possível exploração das mulheres mais pobres em detrimento das pessoas das mais altas classes sociais, resultando em uma depreciação do papel dessas mulheres como seres humanos.

Porém, a mesma crítica pode ser feita a maternidade por substituição altruística, quando em uma relação familiar ou de intimidade, uma pessoa utiliza de seu poder dentro daquele núcleo para convencer a outra a realizar o procedimento para ajudar um parente ou pessoa próxima ${ }^{18}$.

Diz- se também que tanto a maternidade por substituição comercial como a altruística transformam as criança em mercadorias, propriedades. Porém, entregar um bebê como um presente para um casal ou pessoa que

\footnotetext{
18 Banerjee, Swapnendu, “Gestational surrogacy contracts: altruistic or commercial?” (2008), Gokhale Institute of Politics and Economics. Pag. 5.
} 
não possa ter filhos, seria visto de uma maneira valiosa, um ato incomensurável. Enquanto que entregar um bebê em troca de dinheiro seria torná-lo uma coisa fungível, que pode facilmente ser trocada por outra de igual valor, depreciando assim a existência da criança.

Um argumento em favor da maternidade por substituição comercial é a comparação com a doação de esperma realizada pelos homens. A doação de esperma é remunerada na maioria dos casos. Diante desta realidade, porque permitir a remuneração da capacidade reprodutiva masculina e não permitir a remuneração da capacidade reprodutiva feminina?

Colocar a mulher como um ser altruísta, que sempre se sacrifica em nome do próximo só aumentaria a exploração das mulheres, criando uma distinção de género não favorável, segundo esta corrente ${ }^{19}$.

Existe também uma discussão sobre o uso das palavras "altruística" e "comercial" para se definir a maternidade por substituição. O fato das partes combinarem uma remuneração em troca da maternidade por substituição não quer dizer necessariamente que a motivação que as levou até esse contrato não seja altruística. Por outro lado, não receber remuneração alguma pela maternidade por substituição também não significa, necessariamente, dizer que ela é altruística, outros fatores ou vantagens podem estar envolvidos ${ }^{20}$.

O direito de contratar livremente também deve ser colocado aqui como um argumento em favor da maternidade por substituição comercial. O direito de contratar livremente traz consigo a expectativa de que o Estado vai proteger e fazer cumprir os contratos. Na falta de lei especifica que proíba a maternidade por substituição a gestante teria o direito de entrar em um contrato no qual concorda em gestar e dar a luz a uma criança pra uma

\footnotetext{
19 Banerjee, Swapnendu, “Gestational surrogacy contracts: altruistic or commercial?” (2008), Gokhale Institute of Politics and Economics. Pag.6.

${ }^{20}$ Banerjee, Swapnendu, "Gestational surrogacy contracts: altruistic or commercial?" (2008), Gokhale Institute of Politics and Economics. Pag. 7.
} 
pessoa ou casal que não possa conceber naturalmente, em troca de uma remuneração.

Por outro lado, há quem defenda que este tipo de contrato não passaria de uma venda de bebês, contrariando assim as leis existentes e por isso, deveria ser proibido ${ }^{21}$.

\section{Maternidade por substituição comercial como fator de objetificação das partes envolvidas}

Um dos argumentos mais utilizados contra a maternidade de substituição é o de que ela representaria uma maneira de objetificação das mulheres e crianças envolvidas. Transformando as crianças em bens de consumo, mercadorias, e as mulheres em fábrica de bebês.

O papel principal dos pais é amar seus filhos. Crianças existem para serem amadas por seus pais e não utilizadas ou manipuladas por eles em troca de vantagens económicas ${ }^{22}$.

A maternidade por substituição comercial substitui as normas de amor e cuidado entre pais e filhos por normas de mercado. Fazendo com que a filiação seja vista como um direito de propriedade.

Quando normas de mercado determinam a maneira como entendemos e estabelecemos direitos e deveres dos pais em relação a seus filhos, reduzimos as crianças de objetos de amor a objetos de uso. E quando normas de mercado determinam a maneira que entendemos e tratamos a capacidade reprodutiva das mulheres, estamos as reduzindo de sujeitos de respeito a objetos de uso.

Michael Sandel divide os argumentos contra a objetifição em dois grupos, coerção e corrupção ${ }^{23}$.

A coerção se subdivide em dois grupos de acordo com o tipo de dano causado. O primeiro diz respeito a quão voluntário poderia ser o

21 "Surrogate Motherhood" (1990), Buffalo law review, Volume 38. Pag. 534.

22 Anderson, Elizabeth S., "Is women's labor a commodity?" (1990), Philosophy and public affairs, Vol. 19, No. 1. Pag. 75.

23 Sandel, Michael J., "What money can't buy: the moral limits of markets" (1998), The tanner lecture on humam values, delivered at Brasenose College, Oxford. 
consentimento, no contexto da desigualdade social em que vivemos. A decisão do individuo nunca seria totalmente livre e verdadeira se estiver ligada ao recebimento de dinheiro que aquela pessoa não tem como recusar. Por exemplo, uma pessoa pode aceitar vender um rim para alimentar seus filhos que passam fome ${ }^{24}$.

O segundo diz respeito ao acesso desigual que a população tem a determinados bens, também dentro do contexto da desigualdade social. $\mathrm{Ou}$ seja, se certo atividade for objetificada apenas alguns terão acesso a ela, seria então a consagração do beneficio dos ricos em detrimento dos pobres.

Em ambos os casos a coerção como elemento contra a objetificação poderia ser eliminada com a justa distribuição de riquezas e igualdade social $^{25}$.

Já o segundo grupo definido por Sandel, a corrupção, diz que a comercialização denigre o objeto que esta sendo comercializado. Trocar crianças por dinheiro, por exemplo, denigre o valor das crianças porque crianças e dinheiro estão em patamares diferentes de valoração ${ }^{26}$.

Aqui temos que definir que trocas são apropriadas e quais não são. A primeira maneira de se determinar seria analisando as normas sociais e vendo o que é ou não aceito dentro da sociedade.

O problema é as sociedades podem atribuir valores diferentes a uma mesma coisa, então fazer uma definição poderia gerar um relativismo muito grande $^{27}$.

A segunda maneira de se determinar seria analisar a essência do bem em questão. Entende-se que existe sempre algo objetivo e imutável no bem que determina a sua avaliação.

\footnotetext{
24 "The price of everything, the value of nothing: reframing the commodification debate" (2003), Harvard law review. Pag. 690 e 691.

25 "The price of everything, the value of nothing: reframing the commodification debate" (2003), Harvard law review. Pag. 691.

26 "The price of everything, the value of nothing: reframing the commodification debate" (2003), Harvard law review. Pag. 692.

27 "The price of everything, the value of nothing: reframing the commodification debate" (2003), Harvard law review. Pag. 694 e 695.
} 
Assim, definindo a essência do bem pode se determinar o seu valor e estabelecer se determinada troca seria justa ou não. $O$ problema aqui é que existe controvérsia sobre o que constitui a essência de um bem ${ }^{28}$.

Cada argumento contra a objetificação se baseia em um ideal moral diferente. A coerção se baseia em um consentimento ideal, mais especificamente em um consentimento ideal de acordo com as condições sociais nas quais o dono do consentimento estaria inserido. Não seria então uma proibição a comercialização como um todo, e sim, aquela feita em situações de desigualdade social. Não havendo desigualdade a comercialização poderia ser realizada sem problemas.

A corrupção por sua vez seria diferente. Aqui não adiantaria olhar as condições sociais em que as partes estariam inseridas. $\mathrm{O}$ que teria que ser analisado é a importância do bem comercializado. Mesmo que a sociedade não apresentasse injustiça e desigualdade, ainda assim haveriam bens que o dinheiro não deveria poder comprar ${ }^{29}$.

Dentro desse contexto, porque seria errado deixar as pessoas venderem e comprarem bebês?

A primeira resposta se baseia na ideia de coerção. Aqueles que veem a maternidade por substituição como venda de bebês entendem que consentir em gestar uma criança em troca de dinheiro não é uma decisão tão voluntária quanto parece.

Segundo esse entendimento a mãe substituta não está completamente informada no momento em que consente em ficar grávida em troca de dinheiro. Isso ocorre porque ela não teria como saber antes que laços criaria com o bebê durante os nove meses de gravidez.

A segunda resposta se baseia na corrupção, segundo esta corrente, mesmo que o consentimento tenha sido completamente informado e voluntário, trocar uma gravidez, e por consequência um bebê, por dinheiro

\footnotetext{
28 "The price of everything, the value of nothing: reframing the commodification debate" (2003), Harvard law review. Pag. 695.

${ }^{29}$ Sandel, Michael J., "What money can't buy: the moral limits of markets" (1998), The tanner lecture on humam values, delivered at Brasenose College, Oxford. Pag. 95.
} 
não pode ser moralmente aceito pela sociedade, já que devem existir coisas que não se podem vender ${ }^{30}$.

\section{O uso dos "Prebirth parentage orders" nos contratos de maternidade por substituição}

As partes envolvidas nos contratos de maternidade por substituição nos EUA estão sempre em busca de procedimentos legais que possam implementar e ratificar suas intenções.

Cada estado americano tem seu próprio posicionamento acerca do tema baseado nas questões sociais, morais e políticas envolvidas no uso da reprodução humana assistida e mais especificamente na maternidade por substituição. Com isso, os procedimentos podem variar de estado para estado, ou até mesmo dentro de um mesmo estado quando este não tem lei ou jurisprudência especifica sobre a matéria.

O procedimento legal que vem sendo utilizado com mais frequência pelas partes dos contratos de maternidade por substituição para formalizar suas intenções é o "prebirth parentage order". Neste documento, os pretensos pais são declarados os pais legais antes do nascimento da criança $^{31}$.

Muitos benefícios podem surgir com o uso deste tipo de procedimento. Primeiramente, os pretensos pais sendo declarados os pais legais da criança antes mesmo desta nascer poderão ter aceso imediato e exclusivo a ela após o nascimento, podendo decidir e controlar questões medicas que possam surgir.

Além disso, com o uso deste procedimento os nomes dos pretensos pais irão constar nos documentos do hospital e na certidão de nascimento

\footnotetext{
30 Sandel, Michael J., "What money can't buy: the moral limits of markets" (1998), The tanner lecture on humam values, delivered at Brasenose College, Oxford. Pag. 99 e 100.

${ }^{31}$ Snyder, Steven H. e Byrn, Mary Patricia, "The use of prebirth parentage orders in surrogacy proceedings" (2005), Family Law Quartely, Vol. 39, Number 3. Pag. 634.
} 
original da criança, evitando assim o processo de emenda a tais documentos ${ }^{32}$.

O uso do "prebirth parentage order" também traz impacto relevante no plano de saúde da criança nascida através de maternidade por substituição. Uma vez, que ela já é considerada antes mesmo de nascer filha daquele casal podendo desde já participar do plano de saúde da família ${ }^{33}$.

Por último, o uso deste procedimento permite que os pretensos pais participem do parto e de toda a experiencia no hospital da maneira mais próxima possível ao que ocorreria se estivessem tendo um filho de maneira natural.

Mesmo com tantos benefícios, os "prebirth parentage orders" não são apropriados para serem utilizados em todos os casos de maternidade por substituição. O uso ou não deste procedimento deve variar por um lado de acordo com as leis existentes em cada estado sobre a maternidade por substituição e por outro lado de acordo com o tipo de contrato de maternidade por substituição utilizado (maternidade por substituição tradicional ou gestacional).

Na maternidade por substituição tradicional, a mãe substituta utiliza seu próprio material genético, combinado com o material genético do pretenso pai ou de um doador, e por isso, a pretensa mãe não tem nenhuma relação presumida com a criança de acordo com a maioria dos estatutos que determinam a filiação.

A relação entre a pretensa mãe e a criança neste caso precisa ser estabelecida através de algum procedimento de adoção depois do nascimento.

Se o material genético do pretenso pai é utilizado, tanto ele como o marido da mãe substituta, se houver, tem presunção de paternidade. A do

\footnotetext{
${ }^{32}$ Snyder, Steven H. e Byrn, Mary Patricia, "The use of prebirth parentage orders in surrogacy proceedings" (2005), Family Law Quartely, Vol. 39, Number 3. Pag. 634.

${ }^{33}$ Snyder, Steven H. e Byrn, Mary Patricia, "The use of prebirth parentage orders in surrogacy proceedings" (2005), Family Law Quartely, Vol. 39, Number 3. Pag. 635.
} 
pretenso pai baseada na relação genética com a criança e a do marido da mãe substituta baseada na gravidez na constância do casamento.

Nestes casos, o pretenso pai pode, normalmente, se valer de um exame de DNA para estabelecer sua paternidade exclusiva e colocar seu nome na certidão de nascimento da criança. Uma vez que isso ocorra, a pretensa mãe pode se valer do instituto da adoção, como madrasta da criança.

Se, por outro lado, é utilizado o material genético de um doador, ambos os pretensos pais terão que recorrer a um procedimento normal de adoção, com todas as suas burocracias ${ }^{34}$.

Na maternidade por substituição gestacional, a mãe substituta não tem nenhuma relação genética com a criança, o embrião aqui pode ser formado com o material genético da pretensa mãe ou de uma doadora combinado com o material genético do pretenso pai ou de um doador.

Quando o óvulo de uma doadora é utilizado, nem a mãe substituta, nem a pretensa mãe são a mãe genética da criança. A mãe substituta tem a presunção de ser a mãe da criança já que foi ela que deu a luz e por isso, a pretensa mãe terá que recorrer a um procedimento de adoção para figurar como mãe legal da criança.

Aqui, como na maternidade por substituição tradicional, o marido da mãe substituta vai ter presunção de paternidade já que a gravidez se deu na constância do casamento. Se o pretenso pai for o doador do material genético ele vai ter também a presunção de paternidade, só que pela ligação genética, podendo a sua paternidade ser definida então, através de um exame de DNA.

Uma vez que a paternidade do pretenso pai for definida pelo DNA a pretensa mãe poderá se utilizar do procedimento de adoção como madrasta. Se ambos os materiais genéticos forem, por outro lado, de doadores, os pretensos pais terão que recorrer a adoção tradicional.

\footnotetext{
34 Snyder, Steven H. e Byrn, Mary Patricia, "The use of prebirth parentage orders in surrogacy proceedings" (2005), Family Law Quartely, Vol. 39, Number 3. Pag. 639.
} 
Quando, por sua vez, o óvulo da pretensa mãe é utilizado ela tem a seu favor a presunção de maternidade pela ligação genética com a criança. Se o material genético for também do pretenso pai, eles poderão utilizar o DNA para estabelecer sua maternidade e paternidade ${ }^{35}$.

Com isso, entendesse que utilizar um "prebirth parentage order" na maternidade por substituição tradicional ou gestacional que utiliza doadores, ou seja, quando um ou os dois pretensos pais não são geneticamente relacionados a criança e um procedimento de adoção após o nascimento é exigido não parece apropriado.

Por outro lado, quando ambos os pretensos pais são geneticamente relacionados a criança e podem estabelecer a maternidade e a paternidade através das regras dos estatutos de filiação, na maioria deles, através de exame de DNA, o uso do "prebirth parentage order" parece útil e correto ${ }^{36}$.

\footnotetext{
${ }^{35}$ Snyder, Steven H. e Byrn, Mary Patricia, "The use of prebirth parentage orders in surrogacy proceedings" (2005), Family Law Quartely, Vol. 39, Number 3. Pag. 640 e 641.

${ }^{36}$ Snyder, Steven H. e Byrn, Mary Patricia, "The use of prebirth parentage orders in surrogacy proceedings" (2005), Family Law Quartely, Vol. 39, Number 3. Pag. 642.
} 


\section{Capítulo II - Estudo de casos}

\section{$1^{\circ}$ caso: Baby M - Supreme Court of New Jersey, $1988^{37}$}

\section{Aspectos gerais}

$\mathrm{O}$ Baby $\mathrm{M}$ foi o primeiro caso em que a justiça americana enfrentou as questões e peculiaridades envolvidas em um contrato de maternidade por substituição. Em 1988, em meio a diversas polêmicas e pressões de diferentes grupos da sociedade, a Suprema Corte de New Jersey chegou a uma decisão emblemática que deu o tom aos contratos de maternidade por substituição por um longo período de tempo. Este caso serve de paradigma para o estudo desse tipo de contrato até os dias de hoje. Foi através do Baby $\mathrm{M}$ que as inovações trazidas pelas técnicas de reprodução humana assistida (RHA) foram primeiramente colocadas como uma questão social, política e de interesse do direito. Expondo o impacto desse tipo de prática nas estruturas familiares, na natureza da maternidade e no bem estar e correto desenvolvimento das crianças envolvidas.

Neste caso, a justiça americana foi acionada para determinar a validade de um contrato que inauguraria um novo modo de estabelecer relações de filiação. Tendo problemas para gerar seu próprio bebê, o casal William e Elizabeth Stern resolveu, em 1985, recorrer a um contrato de maternidade por substituição. $\mathrm{O}$ contrato estabelecia que através de uma inseminação artificial o material genético de William Stern seria implantado na mãe substituta, Mary Beth Whitehead, já que Elizabeth sofria de esclerose múltipla e uma possível gravidez poderia trazer enormes problemas para a sua saúde, como paraplegia e cegueira. O contrato estabelecia ainda, que após o parto Mary Beth Whitehead entregaria a criança para o casal Stern e faria o que fosse necessário para terminar com seu poder parental, permitindo uma posterior adoção da criança por

\footnotetext{
${ }^{37}$ In re Baby M, 109 N.J. 396, 537 A.2d 1227
} 
Elizabeth Stern, o que a tornaria legalmente filha do casal Stern. Em contrapartida Mary Beth receberia o valor de $\$ 10.000,00$.

O marido de Mary Beth, Richard Whitehead fazia parte do contrato já que pela lei vigente ele seria presumido pai da criança, uma vez que era casado com Mary Beth. Por outro lado, Elizabeth Stern não figurava como parte no contrato, provavelmente para evitar a aplicação do estatuto de adoção que proibia o pagamento em dinheiro em troca de bebês, porém havia uma cláusula que lhe dava a custódia exclusiva da criança em caso de morte do marido.

Paralelamente, foi firmado um contrato entre William Stern e a clínica de fertilização (Infertility Center of New York - ICNY) no valor de $\$ 7.500,00$. A clínica foi responsável por organizar o processo, apresentando as partes umas as outras, explicando as regras e fornecendo o acompanhamento legal para o desenvolvimento do contrato a partir de seus formulários pré existentes. Ambas as partes envolvidas chegaram até este ponto respondendo os anúncios promovidos pela clínica. O casal Stern impulsionado pelo desejo de ter filhos e Mary Beth além de sua simpatia pela causa, uma vez que tinha membros na família com problemas de infertilidade, impulsionada pela recompensa oferecida. Vale ressaltar aqui que todos os envolvidos visando seus próprios interesses minoraram os possíveis problemas provenientes desta transação.

Os problemas começaram a surgir logo após o nascimento da criança, momento no qual Mary Beth percebeu que não conseguiria se separar do bebê, mostrando grande dificuldade em lidar com sua decisão anterior. Contudo, ela foi fiel a sua palavra e entregou a criança ao casal Stern três dias depois de seu nascimento.

Após a entrega, tomada por uma profunda tristeza, Mary Beth foi até a casa do casal Stern pedindo para que eles permitissem que ela ficasse com o bebê por pelo menos uma única semana, com medo que a mãe substituta comete-se suicídio e confiando que ela devolveria o bebê o casal Stern entregou a criança de volta a Mary Beth Whitehead. 
Ao perceber que a criança não seria devolvida, William Stern procurou a justiça exigindo que o contrato de maternidade por substituição fosse cumprido. Em consequência deste ato Mary Beth, com a ajuda de seu marido, fugiu com o bebê para a Florida, onde conseguiu se esconder por três meses, até as autoridades a encontrarem e apreenderem o bebê.

No tempo em que esteve foragida com a criança a mãe substituta realizou varias ligações para o pai biológico, que com autorização da justiça gravou as conversas, para discutir o caso, inclusive ameaçando se matar, matar o bebê e até inventando acusações de abuso sexual contra o mesmo. Assim que a polícia descobriu onde Mary Beth estava a ordem de apreensão do bebê foi cumprida e o mesmo devolvido para o pai biológico.

A decisão em primeira instância reconheceu o contrato como válido, terminando os direitos parentais de Mary Beth e estabelecendo a custódia exclusiva da criança ao pai genético. Além disso, tal decisão permitiu a adoção do bebê por Elizabeth Stern, tudo de acordo com o contrato de maternidade por substituição. $\mathrm{O}$ argumento utilizado foi de que a lei que proíbe o pagamento em dinheiro nos casos de adoção não tem aplicação nos casos de maternidade por substituição, já que não foi elaborada pensando neste fim e que os direitos do pai genético estabelecidos no contrato são constitucionalmente assegurados.

Mary Beth Whitehead apelou desta decisão, utilizando o argumento de que o contrato de maternidade por substituição era inválido uma vez que conflituava com os preceitos do Estado de que o melhor para a criança é ser criada por ambos os pais. Além disso, alegou que tal decisão estaria privando-a de seu direito constitucional de criar sua filha e que tal decisão estaria em conflito com os estatutos que versam sobre a terminação do poder parental e o estatuto de adoção. Com isso, a mãe substituta requereu a custódia da criança e pediu que o pai genético ficasse apenas com o direito de visitação.

Em sua resposta William Stern alegou a validade do contrato, já reconhecida inclusive em primeira instância. Ele também defendeu seu 
direito constitucional a privacidade e a liberdade de procriação. Por fim, alegou que devido a todas as circunstâncias envolvidas pensando-se no melhor interesse da criança a custódia deveria ser dele, sendo terminado o poder parental de Mary Beth Whitehead.

No julgamento do mérito a Suprema Corte de New Jersey entendeu por deferir em parte e modificar em parte a decisão de primeira instância.

\section{Da invalidade do contrato de maternidade por substituição firmado entre as partes $^{38}$}

A Suprema Corte concluiu que o contrato de maternidade por substituição em questão era inválido pois conflituava diretamente com os estatutos existentes e com as politicas públicas do Estado.

Primeiramente, ele iria de encontro às leis existentes que proibiam o pagamento e a aceitação de dinheiro em qualquer situação que envolvesse a adoção de uma criança. Apesar das alegações de William Stern de que o dinheiro foi pago como contraprestação ao serviço prestado por Mary Beth Whitehead a Suprema Corte entendeu ser inequívoco o fato de o dinheiro ter sido usado para conseguir uma renúncia ao poder parental e consequentemente uma adoção.

Tal conclusão se tornou clara através da análise do contrato de maternidade por substituição assinado entre as partes. O contrato previa que o pagamento só seria realizado depois que a mãe substituta desse a custódia da criança para o pai genético e renunciasse aos seus poderes parentais, facilitando a adoção da criança por Elizabeth Stern. Além disso, é preciso salientar que em caso de aborto até os quatro meses de gestação o contrato estipulava que não haveria sequer pagamento, e se o aborto se desse depois deste prazo Mary Beth receberia apenas $\$ 1.000,00$. Não restaram dúvidas de que as partes sabiam o que estavam fazendo, ou seja, criando uma alternativa para fugir das leis que regulavam a adoção, dando e aceitando dinheiro, respectivamente, em troca de uma adoção privada.

\footnotetext{
38 In re Baby M, 109 N.J. 396, 537 A.2d 1227. Pag. 18 a 28.
} 
Nesse ponto, mais uma falha pode ser apontada neste contrato, a renúncia ao poder parental segundo as leis vigentes só poderia acontecer se a mãe genética entregasse a criança direta e voluntariamente a uma agência pré aprovada ou a divisão de infância e família (Division of Youth and Family Services - DYFS) acompanhada de um documento formal abrindo mão de seus poderes parentais. Não havendo esta entrega a cessação só ocorreria se ficasse fortemente provado abandono ou negligência dos pais biológicos em relação a criança. Importante frisar que só existia previsão de documento escrito e assinado renunciando aos poderes parentais nos casos ligados as agencias pré aprovadas e a DYFS, não existia previsão legal de qualquer outro tipo de documento escrito que seja capaz de cessar os poderes parentais, principalmente em casos de adoção privada. Não estando o caso ligado as agências pré aprovados ou a DYFS o poder parental só poderia ser desconstituído quando ficasse inequivocamente provado o abandono ou a negligência dos pais genéticos em relação a criança.

\section{Da cessação do poder parental de Mary Beth Whitehead ${ }^{39}$}

Outro problema apontado para invalidar o contrato foi o fato do mesmo trazer a cessação do poder parental através de uma cláusula irrevogável. Uma vez assinado o contrato Mary Beth Whitehead não teria o direito de mudar de ideia e teria que levar o contrato até o fim, entregando o bebê ao casal Stern. Tal cláusula se mostrava totalmente contrária aos objetivos das leis existentes no Estado de New Jersey, indo de encontro inclusive com a lei que regulava os procedimentos de adoção e que proibia a renúncia da custódia e o consentimento de adoção através de atos irrevogáveis. Mais uma vez ficava provado que o objetivo das partes envolvidas neste contrato era burlar as leis vigentes, criando uma nova forma de cessação do poder parental e de adoção privada.

Consentimento pressupõe informação e liberdade e ambas essas prerrogativas foram ignoradas no caso. Em contratos de maternidade por

\footnotetext{
${ }^{39}$ In re Baby M, 109 N.J. 396, 537 A.2d 1227. Pag. 27 a 30.
} 
substituição como esse, o consentimento é dado muito antes da mulher poder prever as consequências que tal ato poderá gerar. O consentimento aqui é dado antes do nascimento da criança, antes da própria concepção da mesma, e principalmente antes que a mãe substituta possa avaliar que laços serão construídos com aquela criança durante os nove meses de gestação.

Neste tipo de caso a mãe nunca poderia tomar uma decisão totalmente informada pelo simples fato de não ser possível tomar esse tipo de decisão antes do nascimento da criança. Nem a ciência tem ainda elementos suficientes para avaliar que tipo de laços são criados entre a mãe e o bebê durante a gestação e o trabalho de parto.

Além da falta de informação, a Corte entendeu que a mãe substituta não teve liberdade suficientemente garantida para tomar a sua decisão. Nenhuma decisão pode ser considerada absolutamente voluntária quando é induzida por uma recompensa de $\$ 10.000,00$. Não importava aqui qual foi o idealismo que ajudou a motivar essa decisão, não restam dúvidas que o ganho trazido a permeou e governou.

Além de tudo dito anteriormente, mais um fator contribuiu para a invalidação do contrato. O Estado de New Jersey tem como um de seus preceitos a igualdade de direitos de ambos os pais. $\mathrm{O}$ direito do pai não pode se sobrepor ao da mãe e vice versa. É desejável, segundo este conceito que a criança seja criada tanto pelo pai quanto pela mãe, evitando separações desnecessárias, que podem vir a ser altamente prejudiciais ao desenvolvimento da criança.

O contrato de maternidade por substituição fere fortemente este preceito uma vez que separa a criança da mãe independente de sua vontade (que pode ter se modificado após o nascimento) e de suas qualidades, terminando com seu poder parental e dando a custódia exclusiva ao pai. $\mathrm{O}$ pai passa a ter então direitos exclusivos sobre a criança e os direitos a mãe são destruídos.

Uma vez definida a invalidade do contrato a Suprema Corte entendeu que a consequência lógica era a não cessação do poder parental de 
Mary Beth Whitehead, mesmo que ela não ficasse com a custódia da criança ela permaneceria sendo além de mãe biológica, mãe legal da mesma e teria no mínimo seu direito de visitação assegurado.

Já havia sido decido por aquela corte que o fato da criança ficar melhor na custódia de um dos pais não era suficiente para cessar o poder parental do outro. Como já dito anteriormente o poder parental só sofreria cessação se ficasse inequivocamente provado o abandono ou negligência dos pais biológicos.

\section{Dos direitos constitucionais e fundamentais em questão ${ }^{40}$}

$\mathrm{O}$ Baby $\mathrm{M}$ traz à tona diversas discussões sobre direitos fundamentais protegidos tanto na Constituição Federal como na Constituição do Estado de New Jersey: direito à privacidade, direito de procriação, direito de participar e acompanhar o desenvolvimento dos filhos, entre outros.

O principal direito alegado pelo casal Stern é o direito de procriação, enquanto o principal alegado por Mary Beth Whitehead é o de participar ativamente da vida de sua filha.

Em linhas gerais o direito de procriar é o direito de ter filhos naturais seja por meio de relação sexual seja por meio de inseminação artificial. A Suprema Corte entendeu aqui que William Stern não sofreu nenhuma privação desse direito, uma vez que através de uma inseminação artificial Mary Beth ficou grávida, dando a luz uma criança que é tanto filha dela como filha dele.

Os outros direitos que se desenvolvem a partir daí como custódia, visitação, criação, nada tem haver com o direito de procriar, são direitos distintos, não estando de maneira nenhuma dentro do direito de procriação. Tais outros direitos também são constitucionalmente protegidos mas essa proteção envolve outras questões além do direito de procriar. Sob a lógica defendida pelo casal Stern, dizer que tais direitos decorreriam unicamente

\footnotetext{
40 In re Baby M, 109 N.J. 396, 537 A.2d 1227. Pag. 31 a 34.
} 
do direito de procriar seria dizer que o direito de procriar de William Stern daria a ele a custódia da criança enquanto que o mesmo direito de procriar quando aplicado a Mary Beth Whitehead teria exatamente o efeito contrário, lhe impedindo de ter a guarda da mesma.

Já o direito de participar ativamente da vida de sua filha alegado por Mary Beth não pode ser visto como um direito absoluto. A relação de filiação genética não traz em si, automaticamente, esse direito, devendo ficar provado que os pais genéticos são responsáveis e comprometidos com aquela criança. Os pais, mesmo que genéticos, que não se comprometem da maneira correta com a vida e criação dos seus filhos não tem direito adquirido sobre eles apenas por terem laços sanguíneos.

Por outro lado, no caso em tela esse direito não pode ser negado apenas pela existência do contrato de maternidade por substituição. Segundo a Suprema Corte o direito de participar da vida da criança poderia até ser mitigado pela existência de um contrato de maternidade por substituição, porém, para tanto é necessário estar provado que tal contrato foi feito voluntária e conscientemente, como já vimos que não foi o caso do contrato firmado entre as partes aqui.

$\mathrm{O}$ direito à privacidade e a auto determinação também foram levantados pelas partes neste caso, porém a Suprema Corte defendeu que esses direitos tem que ser avaliados de acordo com os efeitos que podem provocar em terceiros de boa fé envolvidos. O direito que as partes tinham de decidir como bem exercer seu direito de procriação não pode em nenhuma circunstância afastar o interesse estatal de proteger a criança envolvida.

Por fim o casal Stern se valeu de interessante alegação, traçando um paralelo entre a maternidade por substituição e a inseminação artificial heteróloga, ou seja, aquela feita com material genético de um doador. Segundo William estava lhes sendo negada a mesma proteção dada as famílias que recorrem a este tipo de inseminação artificial, já que nestes 
casos o marido é presumido pai da criança fruto da inseminação feita em sua mulher com o material de um doador.

O casal Stern se considerava na mesma posição dos casais que recorrem a inseminação artificial heteróloga, só que ao contrário, já que aqui o material genético que veio de fora era o feminino. Para eles em ambos os casos havia uma parte do casal presumidamente infértil e um acordo de que a criança nascida nos procedimentos de inseminação artificial com a ajuda de terceiros seria filha do casal que tinha o projeto parental.

A Suprema Corte entendeu, entretanto, que o tratamento dado pela legislação aos casos não deveria ser o mesmo, já que para eles era óbvio haver diferença entre um simples doador de material genético e uma mãe de substituição. Eles consideraram importante distinguir as duas situações nem que fosse apenas com base no tempo que se leva para doar um material genético e os nove meses envolvidos em uma gestação.

\section{Da custódia da criança ${ }^{41}$}

Uma vez debatidas as questões constitucionais envolvidas a Corte tratou da questão da custódia da criança. Segundo eles, analisando as circunstâncias na qual esta criança já nasceu envolvida, a regra aplicável é a do melhor interesse da mesma.

Importante frisar aqui, que o melhor interesse não está ligado apenas a um estilo de vida, permeado por riquezas materiais, está sim, antes de tudo, ligado a um julgamento de valor sobre o possível futuro da criança, que leva em consideração muitos outros aspectos, principalmente felicidade, bem estar, estabilidade, amor, família e por último o suporte essencial para que a criança em questão desenvolva a sua individualidade, independente da disputa da qual fez parte no passado. A Corte estava então muito mais preocupada com a possível felicidade futura desta criança do que com os bens matérias que uma ou outra família poderiam lhe fornecer.

\footnotetext{
41 In re Baby M, 109 N.J. 396, 537 A.2d 1227. Pag. 34 a 39.
} 
Além disso, a alegação trazida por Mary Beth de que a custódia deveria ser dela para que representasse um desencorajamento da corte ao contrato de maternidade por substituição não foi bem recebida. A Corte defendeu que dizer que tal contrato era inexequível e ilegal já era exemplo suficiente para desencorajar possíveis novas transações deste tipo, não havendo, portanto, motivos para sacrificar o melhor interesse da criança em prol deste exemplo social.

Por todas as razões acima expostas e analisando todos os fatos envolvidos desde o começo desse processo, como a fuga dos Whitehead com a criança para a Flórida, sua separação, o novo casamento e nova gravidez de Elizabeth a Corte entendeu que o futuro do Baby $\mathrm{M}$ parecia mais sólido e garantido se sua custódia ficasse com o pai biológico.

\section{Da visitação da mãe substituta ${ }^{42}$}

Decidida a questão da custódia, passou-se para a questão da visitação da criança. Tendo anteriormente decido que os poderes parentais de Elizabeth estavam mantidos e que ela era a mãe legal do bebê a Corte entendeu que o direito de visitação não lhe poderia ser negado. Custódia e visitação representam a externalização do poder parental e por isso não podem ser suprimidas ao mesmo tempo. Já que Elizabeth não ficou com a custódia do Baby $M$ teria que ter ao menos seu direito de visitação assegurado para que se fizesse valer a decisão da Corte que mantinha seu poder parental.

Entretanto, a Corte entendeu que tal questão deveria voltar para ser discutida em primeira instância, o que não havia ocorrido anteriormente, já que a essa discussão só apareceu em sede de apelação. A Corte remeteu então o problema à primeira instância porém determinou previamente que Elizabeth deveria ter direito a visitação, devendo ser decido apenas sob que condições essa visitação se daria.

\footnotetext{
42 In re Baby M, 109 N.J. 396, 537 A.2d 1227. Pag. 39 e 40.
} 
Por fim a Corte externou sua preocupação com os problemas que a falta de regulação sobre esta nova forma de concepção poderia trazer. Porém, frisaram que a legislação existente à época não impedia que os contratos de maternidade por substituição acontecessem quando a mãe substituta os fizesse voluntariamente, sem ser remunerada ${ }^{43}$ e tendo o direito de mudar de ideia assegurado. A Corte se perguntou como fazer com que a sociedade possa aproveitar os benefícios trazidos pela ciência nesta área reprodutiva evitando os riscos de abuso entre as partes envolvidas. Segundo eles essa pergunta só poderia ser respondida quando a população definisse quais valores estão envolvidos nessa questão.

Esta decisão teve grande impacto na sociedade americana, dando muita visibilidade aos problemas envolvidos nos contratos de maternidade por substituição, como a exploração feminina e a comercialização de crianças.

A partir daqui vários Estados criariam estatutos para regular a questão e por fim, seis estados chegaram a proibir tais contratos no ano de 1988. Em 1992 o Estatuto de Nova York, que proibiu o contrato de maternidade por substituição remunerado, foi considerado o estopim do movimento anti maternidade por substituição ${ }^{44}$. Muitos especialistas chegaram a dizer na época que a maternidade por substituição estava com os dias contados. Porém, isto não aconteceu, aos poucos os interesses políticos e da imprensa no assunto foram diminuindo e o que se viu foi a maternidade por substituição crescendo nas décadas seguintes. Já que o

\footnotetext{
43 A maternidade por substituição pode ser altruística ou comercial, dependendo do fato de a gestante por substituição ser ou não recompensada pela gravidez. Na comercial além do pagamento das despesas naturais que a getante possa ter com a gravidez os pretensos pais the pagam uma remuneração como forma de compensação pelo serviço prestado. Já na altruística os pretensos pais não dão nenhuma remuneração, pagando apenas pelas despesas naturais advindas da gravidez. (Permanent Bureau, "Preliminary report on the issues arising from international surrogacy arrangements" (2012), Prel. Doc. No 10, Hague conference on private international law) $44 \mathrm{O}$ movimento anti maternidade por substituição surgiu através da discussão gerada pelo Baby M. Tal movimento foi incentivado principalmente pelos grupos feministas e religiosos que defendiam que o contrato de maternidade por substituição representava a venda de bebês e a objetifição das mulheres, transformando - as em fabricas de crianças. Além disso o movimento entendia que tais contratos geravam a exploração de mulheres menos favorecidas que não possuíam capacidade para compreender as consequências das decisões que estavam tomando. Para este movimento a maternidade por substituição diminui a importância reprodutiva da mulher e da família como instituição a ser preservada.
} 
tema passou a ser tratado mais pelo ponto de vista do bem que traz aos casais que não podem ter filhos naturalmente do que do ponto de vista de exploração feminina e da comercialização de crianças ${ }^{45}$.

\section{$\underline{2^{\circ} \text { caso: Calvert v. Johnson - Supreme Court of California, } 1993^{46}}$}

\section{Aspectos gerais}

Calvert é outro notório caso americano que contribuiu para a mudança das bases dos contratos de maternidade por substituição nos Estados Unidos e no mundo depois que o Baby M atraiu atenção mundial para o tema.

Mark e Crispina Calvert eram casados e desejavam ter filhos, porém, Crispina já havia anteriormente se submetido a uma histerectomia por motivos médicos o que a impossibilitava de engravidar. Ocorre que mesmo não podendo engravidar Crispina ainda era capaz de produzir óvulos saudáveis o que fazia com que eles considerassem a maternidade por substituição uma opção para o seu caso.

Anna Johnson tomou conhecimento da história do casal através de uma colega de trabalho e se ofereceu para servir como mãe substituta para os Calvert. Anna já tinha uma filha, nascida em 1987.

Em janeiro de 1990 as partes assinaram o contrato de maternidade por substituição no qual acordavam que um embrião criado com o material genético de Mark e Crispina seria implantado em Anna e que a criança nascida através deste procedimento seria filho do casal Calvert. Além disso, neste contrato Anna abria mão de todos os seus poderes parentais em favor de Mark e Crispina. Em contra partida, o casal pagaria \$10.000,00 como recompensa e faria um seguro de vida em nome do Anna no valor de \$ 200.000,00.

\footnotetext{
${ }^{45}$ Scott, Elizabeth S., "Surrogacy and the Politics of Commodification" (2008). Columbia Public \& Legal Theory Working Papers. Pag. 13 e 14.

${ }^{46}$ Johnson v. Calvert, 5 Cal4th 84, 851 P.2d 776
} 
Menos de um mês depois de assinado o contrato Anna ficou grávida. Ainda durante a gestação a relação entre as partes se desgastou, Mark descobriu que Anna já havia sofrido diversos partos prematuros e abortos e Anna reclamava que o casal Calvert não estava se esforçando para conseguir o seguro de vida e assim cumprir o contrato. Além disso, Anna se sentiu abandonada pelo casal durante uma complicação que poderia gerar um parto prematuro ocorrida em junho.

Após está complicação Anna mandou uma carta para o casal Calvert pedindo um balanço dos depósitos já realizados em seu favor e ameaçando não entregar a criança caso eles não o apresentassem. Mark e Crispina então ingressaram com uma ação, pedindo a declaração de que eram os verdadeiros pais da criança que estava para nascer. Anna também entrou com uma ação pedindo a declaração de que ela era a mãe da criança.

A criança nasceu em setembro e exame de DNA comprovou que Anna não era a mãe genética. As partes então concordaram com ordem da corte de que a criança deveria ficar com Mark e Crispina até a resolução do caso com direito de visitação de Anna assegurado.

$\mathrm{O}$ caso foi julgado em primeira instância em outubro do mesmo ano. Depois de ouvidas as partes e analisadas as evidências ficou decidido que Mark e Crispina eram os pais genéticos, biológicos e naturais da criança e que Anna não tinha direito ao poder parental sobre a mesma já que o contrato de maternidade por substituição foi considerado válido e exequível. Anna perdeu também o direito de visitação.

Anna apelou dessa decisão e por isso a Suprema Corte fez a revisão do caso.

\section{Da intenção como principal fator para se definir a questão da maternidade ${ }^{47}$}

No caso em tela tanto Anna quanto Crispina apresentaram provas válidas em favor de suas maternidades já que o Uniform Parentage Act

\footnotetext{
47 Johnson v. Calvert, 5 Cal4th 84, 851 P.2d 776. Pag. 6 a 17.
} 
$(\mathrm{UPA})^{48}$, único estatuto definindo poder parental a época, considerava tanto a consanguinidade genética (apresentação de exame de DNA) como o parto meios de provas hábeis.

Ocorre que as leis na Califórnia reconhecem apenas uma mãe natural para cada pessoa independente até mesmo dos avanços trazidos pela medicina reprodutiva que possibilitaram situações sui generis como esta onde Anna, não Crispina, deu a luz a criança e Crispina, não Anna, é geneticamente ligada a ela.

A maioria da Corte entendeu então que havendo provas de maternidade de ambos os lados o fator determinante a ser analisado era a intenção das partes manifestada no contrato de maternidade por substituição, ou seja analisar de quem era verdadeiramente o projeto parental.

Mark e Crispina desejavam um filho geneticamente ligado a eles mas estavam fisicamente impedidos de concretizar este desejo sem a ajuda das técnicas de reprodução humana assistida. Foram eles que realizaram os passos necessários para a fertilização in vitro, sem as suas intenções de terem um filho a criança em disputa não iria sequer existir. $O$ projeto parental do casal foi a primeira causa, o primeiro passo para a existência desta relação.

Anna concordou em ajudar o casal, prestando um importante serviço a eles. Todos os envolvidos sabiam que o objetivo do contrato era trazer o filho de Mark e Crispina ao mundo. Anna nunca havia antes manifestado seu desejo de ser a mãe da criança.

Por isso, mesmo o UPA reconhecendo tanto a consanguinidade quanto o parto como meios de se provar a maternidade, quando os dois meios não coincidem na mesma mulher a mãe natural deve ser considerada aquela que tinha a intenção de criar aquela criança como sua em primeiro

\footnotetext{
48 O Uniform Parentage Act (UPA) era parte de um conjunto de legislações introduzido em 1975 pelo Senate Bill n 347, buscando eliminar a distinção legal entre filhos legítimos e ilegítimos. Tal ato não foi produzido para resolver questões envolvendo maternidade por substituição, que eram praticamente desconhecidas em 1975, porém o ato pode ser aplicado em qualquer caso envolvendo determinação de paternidade ou maternidade.
} 
lugar. Do mesmo jeito que em situações de doação de óvulo, quando uma mulher engravida de uma criança formada pelo óvulo de uma doadora na intenção de criar a criança como sua a mulher que deu a luz deve ser considerada a mãe natural.

A Corte também afastou sob este argumento a opinião do amicus curiae, The American Civil Liberties Union (ACLU), de que a criança deveria ter duas mães. Eles entenderam que mesmo com o divórcio possibilitando uma infinidade de acordos entre as famílias nas sociedades modernas não haveria razão para fazer com que o casal Calvert tivesse que dividir seu bebê com uma terceira pessoa com a qual eles tinham pouquíssima relação.

Mark e Crispina eram os pais genéticos da criança e era deles também a intenção de ter aquele filho, além disso tinham todas as condições necessárias para dar a criança um lar estável e amoroso. Dividir o poder parental com Anna significaria nesse caso diminuir o papel de Crispina como mãe.

Não foi aceito também o argumento de que Anna não teria informações e conhecimento necessários para consentir em gestar e depois entregar a criança ao casal Calvert. Anna era enfermeira, com boa educação e formação e já tinha uma filha, tendo então tanto conhecimento intelectual como experiencia de vida necessários para dar um consentimento válido.

A corte decidiu então que Mark e Crispina eram os pais genéticos, biológicos e naturais da criança, não tendo Anna nenhum poder parental sobre a mesma.

\section{Do voto vencido - o melhor interesse da criança como fator determinante para se definir a questão da maternidade ${ }^{49}$}

$\mathrm{O}$ voto vencido levantou interessante debate. Como já foi dito o UPA não seria capaz de determinar quem é a mãe natural da criança já que reconhece tanto a relação genética, criada com o fornecimento do óvulo

\footnotetext{
49 Johnson v. Calvert, 5 Cal4th 84, 851 P.2d 776. Pag. 18 a 32.
} 
quanto o parto como meios hábeis para se provar a maternidade. E diante da divisão desses momentos entre duas mulheres diferentes ele não traria meios de se decidir qual é a mãe natural. Confrontada, a maioria da Corte decidiu adotar a intenção, o projeto parental, como fator predominante nesta decisão mas o voto vencido entendeu que o melhor fator a se aplicar seria o melhor interesse da criança.

Segundo este entendimento a intenção dos pretensos pais de ter o bebê e cria-lo, apesar de servir como um importante e forte argumento, não seria o melhor fator a ser adotado uma vez que uma regra inflexível como essa nem sempre protegeria o melhor interesse da criança. Através da adoção deste paradigma, apesar de no caso concreto analisando-se o melhor interesse da criança a decisão adequada também seria reconhecer Crispina como a mãe natural, a Corte estaria criando uma regra para os futuros casos que nem sempre resultaria na melhor decisão.

A ideia de que a intenção dos pretensos pais é o fator decisivo para a existência daquela criança é contestada pelo voto vencido, segundo sua concepção gestar a criança por nove meses e depois lhe dar a luz também é fator decisivo para a existência da mesma e não poderia ser afastado. Tanto a gestante de substituição quanto os pretensos pais são indispensáveis para a realização do contrato e por consequência a existência da criança.

A mulher que carregou a criança em seu corpo por nove meses e depois a trouxe ao mundo tem argumentos substanciais para querer se estabelecer como a mãe. Ela teve uma contribuição indispensável e única para a formação daquele ser, assim como a pretensa mãe. Não devendo seu papel nessa transação ser diminuído.

O comprometimento da mãe substituta com a criança que ela esta gestando não é só físico, é também psicológico e emocional. A Suprema Corte já se posicionou ${ }^{50}$ que ralação do pai com o filho se expressa principalmente com a responsabilidade que o mesmo assume com a criança após seu nascimento enquanto que no caso da mãe essa relação nasce em

${ }^{50}$ Lehr v. Robertson, 463 U.S. 248, 103 S.Ct. 2985, 77 L.Ed.2d 614. 
um momento anterior, já que é ela que carrega e cuida da criança até o seu nascimento dentro do seu próprio corpo.

Sob esta ótica não se poderia tratar uma criança como propriedade e dar o direito a possui-la a seu "inventor", ou uma invenção. As noções mais básicas de dignidade da pessoa humana determinam ser completamente inapropriado ver seres humanos sob a ótica da propriedade.

Não havendo uma legislação especifica para se decidir o caso e partindo do principio que estamos lidando com a vida e o futuro de uma criança não se pode analisar o caso sob a ótica da propriedade e do direito contratual, o correto a se fazer, segundo o voto vencido, seria analisar a situação sob as regras do direito de família.

A decisão que determinasse quem teria o poder parental sobre a criança implicaria diretamente no seu bem estar e desenvolvimento futuro e as decisões que decidem sobre esse tipo de controvérsia normalmente usam o bem estar da criança como fundamento principal.

O melhor interesse da criança não depende exclusivamente da situação económica das partes, já que se o fosse os pretensos pais normalmente estariam em vantagem. Outros fatores como estabilidade, ensinamentos éticos, morais e apoio ao desenvolvimento intelectual são mais importantes do que a situação económica propriamente dita. Por isso, o voto vencido entende que a intenção, o projeto parental seria uma questão relevante a ser tratada dentro da análise do melhor interesse da criança mas não poderia de maneira alguma ser analisada sozinha.

\section{Maternidade por substituição tradicional $x$ Maternidade por substituição gestacional}

Como dito anteriormente, a maternidade por substituição vêm sendo dividida em dois grandes grupos. A maternidade por substituição tradicional, onde a gestante substituta contribui com seu próprio material

51 Johnson v. Calvert, 5 Cal. $4^{\text {th }} 84,851$ P.2d 776. Pag. 27. 
genético e a maternidade por substituição gestacional, onde a gestante substituta apenas gesta o bebê, não tendo nenhuma ligação genética com o mesmo.

Calvert foi um importante caso que levantou a questão da maternidade por substituição gestacional. A maternidade por substituição tradicional era a regra até o final dos anos $80^{52}$.

Após esta decisão a Califórnia se tornou um grande centro para a prática deste tipo de contrato. Além disso, a atenção dada a distinção entre a maternidade por substituição tradicional e a maternidade por substituição gestacional fez com que muitos Estados viessem a favorecer o uso da segunda como espécie padrão de contrato de maternidade por substituição.

Durante toda a discussão anteriormente levantada, inclusive pelo Baby M, pouca atenção havia sido dada a ligação entre genética e gestação, já que esses dois elementos sempre andavam juntos até aqui. A maternidade por substituição gestacional veio mostrar que não sendo ligadas geneticamente aos bebês as gestante de substituição não desenvolvem os laços maternais que anteriormente eram desenvolvidos pelas gestantes por substituição nos contratos tradicionais, já que não veem aquele bebê como próprios e sim desde o início o entende como dos pretensos pais ${ }^{53}$.

A mudança no tipo de contrato mudou o foco da situação de venda de bebês e exploração feminina para importante função social exercida para ajudar casais que não são capazes de ter filhos sozinhos.

A separação da gestação da genética aumentou tanto a demanda dos pretensos pais pelos contratos de maternidade por substituição quanto a demanda das gestantes por cumprirem esse papel. Os pretensos pais se sentem mais seguros para entrar nesse tipo de contrato já que podem controlar melhor a formação genética de seu bebê e suas únicas preocupações passam a ser a boa saúde da gestante e a maneira como ela

\footnotetext{
${ }^{52}$ Scott, Elizabeth S., "Surrogacy and the Politics of Commodification" (2008). Columbia Public Law \& Legal Theory Working Papers. Pag. 15

${ }^{53}$ Scott, Elizabeth S., "Surrogacy and the Politics of Commodification" (2008). Columbia Public Law \& Legal Theory Working Papers. Pag. 40.
} 
vai viver e se cuidar durante a gravidez. E as gestantes também se sentem melhores já que não estão abrindo mão de seus próprios filhos ${ }^{54}$.

${ }^{54}$ Scott, Elizabeth S., "Surrogacy and the Politics of Commodification" (2008). Columbia Public Law \& Legal Theory Working Papers. Pag. 42. 


\section{Conclusão}

Não restam dúvidas de que a maternidade por substituição é uma técnica que veio para ficar. A possibilidade de se realizar a vontade há muito conhecida de se deixar descendentes genéticos que nos perpetuarão nesse mundo aliada as mudanças sociais que além de aumentar as taxas de infertilidade, fizeram surgir cada vez mais novas modalidades de família que não seriam possíveis através dos métodos tradicionais de reprodução só provam este fato.

Com isso, faz-se necessário o desenvolvimento de legislações especificas a respeito do tema em todo o mundo. Uma realidade tão latente não pode continuar a ser respondida através das velhas legislações de direito de família, que na maioria dos casos não visavam a reprodução humana assistida, muito menos a maternidade por substituição.

Uma regulação bem trabalhada sobre o tema, estabelecendo claramente regras de conduta para todas as partes envolvidas, pode ajudar, no mínimo, a mitigar os receios dos diversos grupos da sociedade em relação a está pratica ${ }^{55}$. Permitindo que a reprodução humana assistida, em geral, e a maternidade por substituição, mais especificamente, cumpram o principal papel ao qual se propõem, ou seja, colaborar com o desejo de procriar das mais variadas formas de família, que por qualquer motivo não possam ou não queiram tem filhos naturalmente.

Nesse ponto, como dito anteriormente, a análise do caso americano pode ser útil, já que é um país precursor na utilização da maternidade por substituição e no estudo dos impactos e divergências levantadas por ela. Muito embora, no próprio EUA ainda hajam lacunas e incertezas sobre o tema em diversos estados, muitos outros já se posicionaram e inclusive legislaram sobre o assunto.

Tal experiência então pode ser analisada e utilizada como exemplo nos demais países e até mesmo pelas organizações internacionais na

55 Scott, Elizabeth S., "Surrogacy and the Politics of Commodification" (2008). Columbia Public Law \& Legal Theory Working Papers. Pag. 49 
tentativa de se criar uma solução global para o tema já que o turismo reprodutivo e as implicações trazidas por ele são uma realidade preocupante.

Nesse contexto, é importante se pensar na criação de um sistema de proteção mínimo aos envolvidos, principalmente aos mais sujeitos a exploração, ou seja, mulheres e crianças, além de um sistema de cooperação internacional buscando evitar abusos e dar previsibilidade as partes ${ }^{56}$.

56 Permanent Bureu, "A preliminary report on the issues arising from international surrogacy arrangements" (2012), Prel. Doc. No 10, The Hague conference on private international law. Pag. 27. 


\section{Bibliografia}

Campbell, Angela, "Conceiving parents through law" (2007), International Journal of law, policy and the family.

Kingregan, Charles P., "Collaborative Reproduction and Rethinking Parentage" (2008), Journal of the American Academy of Matrimonial Lawyers.

Permanent Bureau, "Preliminary report on the issues arising from international surrogacy arrangements" (2012), Prel. Doc. No 10, Hague conference on private international law.

Ingram, John Dwight, "Surrogate gestator: a new and honorable profession" (1993), Marquette law review, volume 76.

Walker, Veneta Cormier, "Surrogate motherhood in California: Will the real (legal) mother please stand" (2000), 9 San Francisco Law Review, 33.

Ryznar, Margaret, "International commercial surrogacy and its parties" (2010), The John Marshall Law Review.

Rae, Scott B., "Whose child is this? Defining the mother in surrogate motherhood arrangements" (1994), Journal of women's health, Volume 3, Number 1.

Banerjee, Swapnendu, "Gestational surrogacy contracts: altruistic or commercial?" (2008), Gokhale Institute of Politics and Economics.

Gugucheva, Magdalina, "Surrogacy in America" (2010). Council for Responsible Genetics. 
Anderson, Elizabeth S., "Is women's labor a commodity?" (1990), Philosophy and public affairs, Vol. 19, No. 1.

Sandel, Michael J., "What money can't buy: the moral limits of markets" (1998), The tanner lecture on human values, delivered at Brasenose College, Oxford.

Snyder, Steven H. e Byrn, Mary Patricia, "The use of prebirth parentage orders in surrogacy proceedings" (2005), Family Law Quartely, Vol. 39, Number 3.

Scott, Elizabeth S., "Surrogacy and the Politics of Commodification" (2008). Columbia Public \& Legal Theory Working Papers.

Stumpf, Andrea E., "Redefining Mother: A legal matrix for new reproductive technologies" (1986), Yale Law Journal Company.

Wertheimer, Alan, "Two questions about surrogacy and exploitation" (1992), Philosophy \& Public affairs, Princeton University Press.

In re Baby M, 109 N.J. 396, 537 A.2d 1227

Johnson v. Calvert, 5 Cal4th 84, 851 P.2d 776

Lehr v. Robertson, 463 U.S. 248, 103 S.Ct. 2985, 77 L.Ed.2d 614 